\section{Et korstog mot legemiddelindustrien}

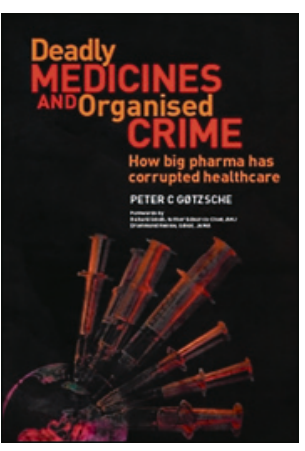

Peter C. Gøtzsche

Deadly medicines and organised crime

How big pharma has corrupted healthcare.

310 s, tab, ill. London: Radcliffe Publishing.

2013. Pris GBP 25

ISBN 978-1-84619-884-7

Peter C. Gøtzsche (f. 1949) er en dansk lege som har satt spor etter seg som en fargerik og intens kritiker av medisinske «sannheter». Jeg har hatt gleden, eller skrekken, av å treffe Gøtzsche ved noen anledninger, sist på et møte ved det europeiske legemiddelkontoret (EMA) om adgang til data fra kliniske studier. Han holdt et flammende innlegg om viktigheten av dette. Med bakgrunn som biolog, kjemiker og lege, yrkeserfaring fra legemiddelindustrien, professor og leder av det nordiske Cochrane-senteret har han solide kunnskaper. Disse kunnskapene bruker han for det er verdt - og litt til i denne boken. Det er en fascinerende bok med svakheter, nærmest som en kriminalroman der historien ikke henger helt sammen.

Boken har 22 kapitler, med titler som «Confessions from an insider», «Very few patients benefit from the drugs they take» og «Intimidation, threats and violence to protect sales». Språket skjemmes av overdrivelser og utropsord, slik som «corruption», «fools» og «fraud».

Med snart 20 års fartstid ved Legemiddelverket smiler jeg gjenkjennende til noen av de historiene han trekker frem. «Merck, where the patients die first» (kapittel 13) beretter om Vioxx (rofekoksib) og krumspring foran og bak scenen før legemidlet ble trukket i 2004.

For eksempel at IT-kriminalteknikk avslørte at tre tilfeller av hjerteinfarkt ble fjernet to dager før et manuskript ble sendt til New England Journal of Medicine.

Et kapittel tar for seg hvordan legemiddelfirmaer har truet og forfulgt fagfolk som har vært kritiske. Her finnes mange opplegg til kriminalhistorier. Et visdomsord fra en av psykiatrilærerne mine i studiet falt meg i hu: «Husk at paranoide kan ha fiender.» Det er vanskelig å tro, men noen kolleger har vært utsatt for regelrette bakvaskelseskampanjer.

Gøtzsche, som er en disippel av kunnskapsbasert medisin, svikter i noen sammenhenger sitt kall og bringer påstander som neppe er riktige. Jeg tror, som Gøtzsche, at full tilgang til alle data fra kliniske studier på enkeltpasientnivå er et viktig tiltak for å hindre skjevpublisering og manipulering av fakta. Selv burde han vært mer nøyaktig i boken.

Til tross for svakhetene hadde jeg stor glede av boken. For dem som er interessert i temaet, vil jeg anbefale Bad pharma. How drug companies mislead doctors and harm patients av Ben Goldacre eller On the take. How medicine's complicity with big business can endanger your health av Jerome P. Kassirer fremfor, eller i tillegg til, denne boken.

\section{Steinar Madsen}

Medisinsk fagdirektør, Statens legemiddelverk Oslo

\section{Mulighet for liv}

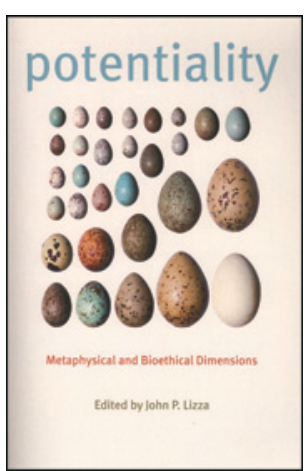

John P. Lizza, red

Potentiality

Metaphysical and bioethical dimensions.

276 s, ill. Baltimore, MD: The Johns Hopkins

University Press, 2014. Pris USD 50

ISBN 978-1-4214-1174-3

Hva mener vi med at «skaden er irreversibel» slik at videre behandling er nytteløs? Eller med at «fosteret har rett på beskyttelse», eksempelvis etter svangerskapsuke 12? I begge ender av livet møter vi spørsmålet om når biologisk liv kan avsluttes. I begge tilfeller må vi vurdere «moralsk status». John Lizza peker i sin antologi Potentiality på at spørsmål om moralsk status og irreversibel tilstand koker ned til hva vi mener med potensialitet: Har fosteret potensial til å bli en person? Har den skadede potensial til å komme til bevissthet og «bli seg selv»? Kjernen i potensialitetsargumentet er at noen av de rettighetene som en person har, også gjelder for samlede enheter som har potensial til å bli en person (igjen).

Antologien er delt $i$ tre deler med blant annet tekster av ledende filosofer og bioetikere, som Peter Singer og Joel Feinberg. Den første delen består av filosofiske drøftinger av hva som menes med potensialitet og andre tilsvarende termer innen bioetikk. Den andre delen består av tekster som bruker potensialitet i debatten om fosterets moralske status, abort og bruk av stamceller i forskning. Den tredje og siste delen setter søkelyset på potensialitet på slutten av livet, og særlig ved ulike definisjoner av død.

I tillegg til et nennsomt utvalg av tekster gir John Lizza en nyttig og oversiktlig introduksjon om potensialitet. Han viser hvordan potensialitetsargumentet finnes i en rekke varianter, og hvordan potensialitet henger nøye sammen med begreper som disposisjon og mulighet (possibility). I tillegg viser han hvordan kritikken av potensialitet i hovedsak har rettet seg mot én bestemt forståelse av potensialitet. Eksempelvis avviser Peter Singer og andre potensialitet, fordi det skulle gi prinsen samme rettigheter som kongen (fordi han har potensialitet til å bli konge), og fordi potensialitetsargumentet gir absurde følger, slik som at også sæd- og eggceller har krav på beskyttelse, siden de potensielt kan bli til personer. Lizza viser hvordan slike innvendinger bare gjelder for enkelte forståelser av potensialitet, og at den som vil argumentere troverdig for abort, stamcelleforskning og organdonasjon på bakgrunn av irreversibelt opphør av hjerte- og åndedrettsfunksjonen, må skjerpe argumentasjonen og ta potensialitetsargumentet på alvor.

Boken er derved en nyttig tankevekker for tilhengere og motstandere av de mest brennbare temaene i moderne bioetikk: spørsmål om liv og død - om tilblivelse og opphør. Den samler sentrale tekster som argumenterer både med og mot potensialitetsargumentet. De teoretiske aspektene som boken drøfter, er høyst relevante for konkrete problemstillinger, slik som abort, assistert befruktning, fosterdiagnostikk, behandlingsavslutning, organdonasjon og stamcelleforskning, for å nevne noen. Selv om dette nok er en bok som blir mest lest av dem som er spesielt interessert i grunnlagsspørsmål i medisinen, kan den med letthet anbefales til alle som mener at de har begrunnede svar på noen av medisinens vanskeligste spørsmål.

Bjørn Hofmann

Professor, Avdeling for helse, omsorg, sykepleie Høgskolen i Gjøvik 